INTER NATIONAL MONETARY FUND

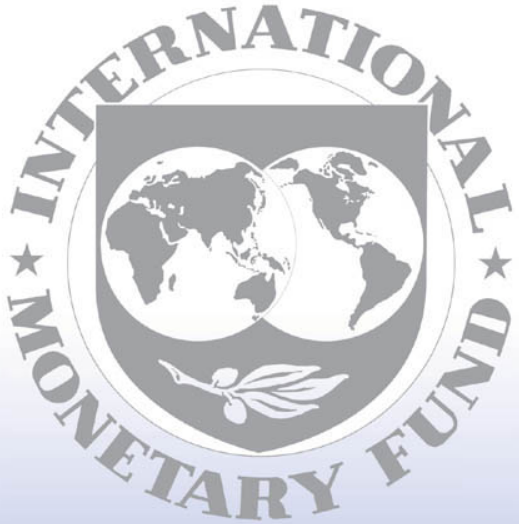

Staff

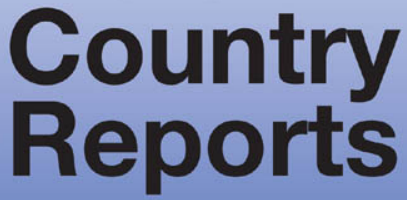




\section{Republic of Belarus: Selected Issues}

This paper was prepared based on the information available at the time it was completed on October 6, 2009. The views expressed in this document are those of the staff team and do not necessarily reflect the views of the government of Republic of Belarus or the Executive Board of the IMF.

The policy of publication of staff reports and other documents by the IMF allows for the deletion of market-sensitive information.

Copies of this report are available to the public from

International Monetary Fund • Publication Services

700 19th Street, N.W. • Washington, D.C. 20431

Telephone: (202) 623-7430 • Telefax: (202) 623-7201

E-mail: publications@imf.org • Internet: http://www.imf.org

\section{International Monetary Fund \\ Washington, D.C.}




\section{INTERNATIONAL MONETARY FUND}

\section{REPUBLIC OF BELARUS}

\section{Selected Issues}

Prepared by Shuang Ding and Dmitriy Kovtun (all EUR)

Approved by the European Department

October 6, 2009

Contents

I. Is There a Need for Further Adjustment in the Exchange Rate? $\underline{2}$

A. What do Basic Indicators Tell us About Current Account Sustainability? ................. 2

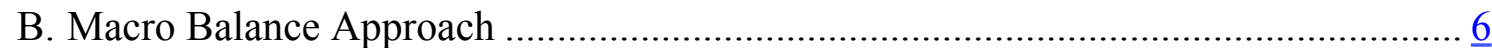

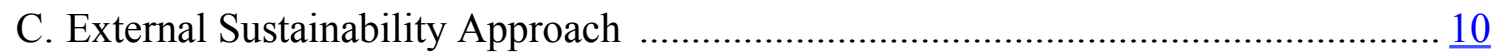

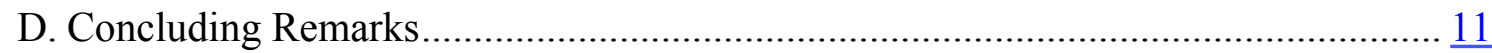

Figure

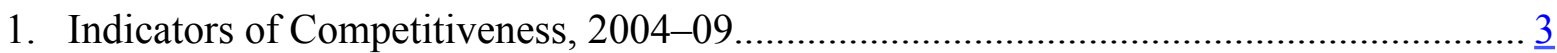

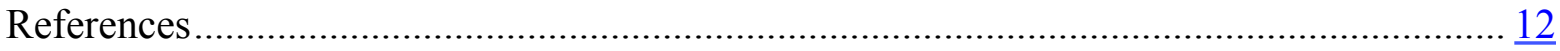

II. Sources of Recent Growth and Prospects for Future Growth........................................ 13

A. Overview of Growth Factors ………............................................................. 14

B. Sources of Growth From Production Function Approach ………….......................... $\frac{18}{20}$

C. Prospect for Future Growth …………………................................................ 20

D. Improving Growth Potential Through Reforms................................................... 23

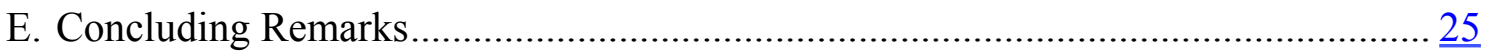

Box

1. The Impact of Changing Energy Prices on Belarus's Net Exports................................. 22

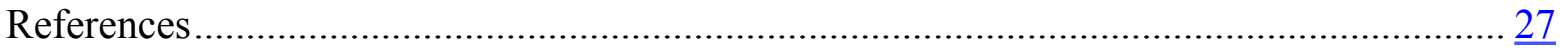




\section{Is There A NeEd For Further AdJUSTMENT IN THE EXChANGE RATE? ${ }^{1}$}

The global financial crisis that erupted in the late 2008 had a profound impact on Belarus's economy. The unprecedented external shock necessitated a strong set of corrective measures, including exchange rate adjustment. The central question is whether the measures in the exchange area are sufficient to restore current account sustainability. This paper attempts to answer this question by examining various pieces of evidence-including basic indicators of competitiveness as well as the macroeconomic balance and external sustainability approaches. The evidence points to the conclusions that (i) the substantial misalignment observed in the end of 2008 has been largely corrected and the need for further substantial exchange rate adjustment is not evident (although a small correction could be justified). Sustainability of the current rate, however, is conditional on maintaining tight domestic demand policies necessary to support the peg over the medium term.

1. Section A discusses several indicators of competitiveness placing them in the context of macroeconomic developments. Section B elaborates on the application of the macroeconomic balance approach based on a model used in the IMF's CGER assessments. Section C applies the external sustainability approach - also used in CGER assessmentsbased on the simple intertemporal budget constraint. Section D offers concluding remarks.

\section{A. What do Basic Indicators Tell us About Current Account Sustainability?}

\section{Prior to the crisis, basic indicators showed no signs of erosion of export} competitiveness, suggesting that the exchange rate was broadly in line with equilibrium (Figure 1). The CPI-based REER — which can be regarded as an indicator of price competitiveness - had been depreciating steadily until August 2008. The REER based on the unit labor cost (ULC) suggests that cost competitiveness had been improving since Q1 2006. Exports grew at a fast pace - in the first half of 2008, they increased by 62 percent in value terms and by 13 percent in volume terms, suggesting that export competitiveness was broadly adequate.

3. The global financial crisis, which produced a strong negative shock transmitted mainly via trade and exchange rate channels from the sagging Russian economy, led to a loss of current account sustainability. During August-December 2008, the REER appreciated by 19 percent due to the depreciation of the Russian ruble. Exports in the fourth quarter of 2008 shrank by 12 percent relative to the fourth quarter of 2007 while imports declined by only 2 percent, and the population's demand for foreign currency spiked, exerting strong pressure on reserves. The authorities intervened heavily to support the peg to the US dollar. These developments indicated a loss of competitiveness and pointed to a possible disequilibrium in the exchange rate.

\footnotetext{
${ }^{1}$ Prepared by Dmitriy Kovtun, with input from Shuang Ding and Pritha Mitra.
} 
Figure 1. Belarus: Indicators of Competitiveness, 2004-09
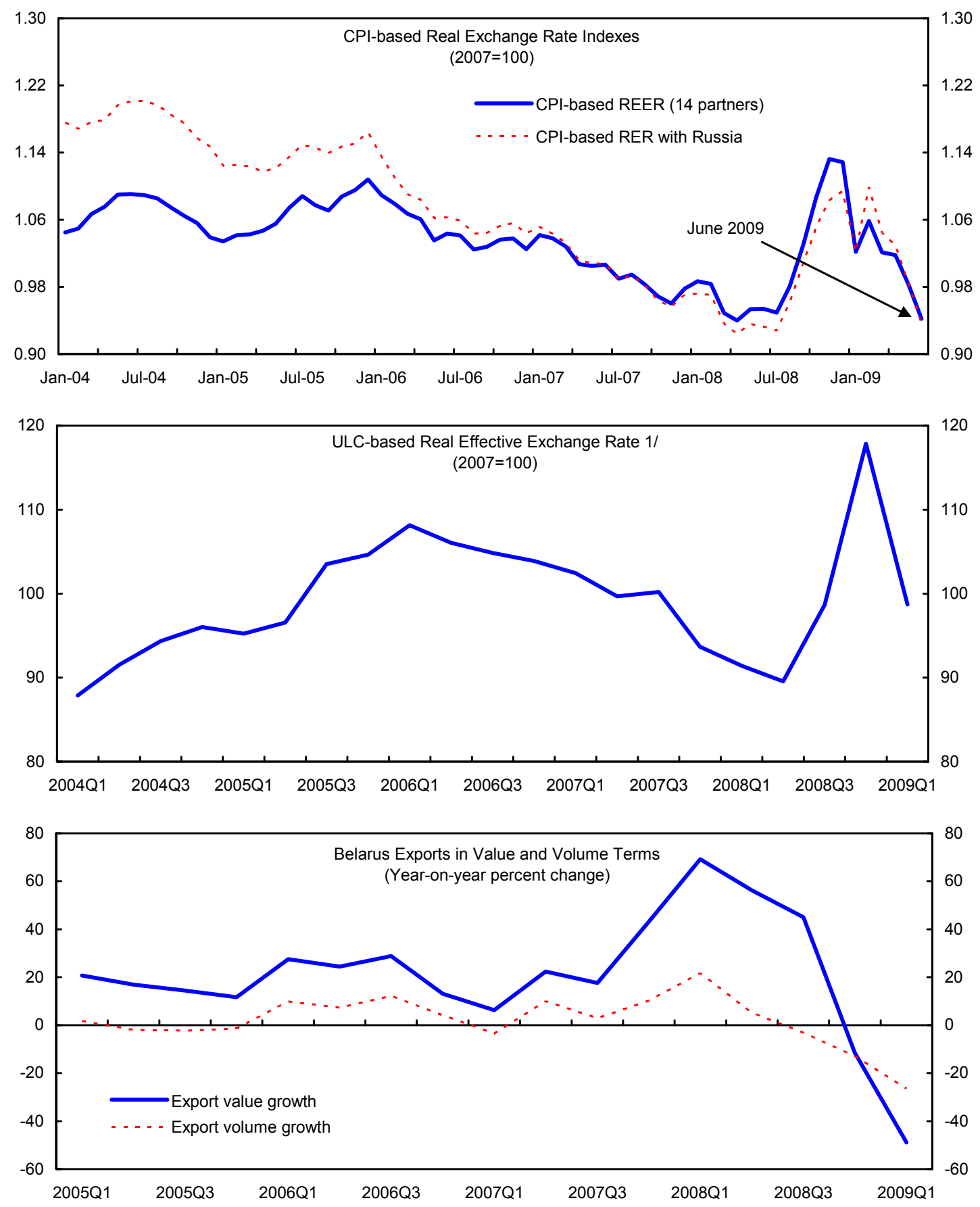

Sources: National Bank of the Republic of Belarus; BelStat; and IMF staff estimates.

$1 /$ The index is constructed using data from 3 trading partners: Russia, the EU and the U.S. 
4. The authorities devalued the rubel against the US dollar in January 2009 and repegged against the basket consisting of the Russian ruble, the US dollar and the Euro, but exchange pressures persisted. In the first five months of 2009, exports declined by nearly 50 percent while imports fell by only 30 percent, resulting in the current account deficit nearly twice as large as in the corresponding period of 2008. The pressures on reserves were exacerbated by substantial currency substitution driven by public expectations of another devaluation. Given the dwindling financial account inflows, the NBRB supported the exchange rate by substantial intervention amounting to over $\$ 1.1$ billion in the first quarter and $\$ 1$ billion of the second quarter, losing some $\$ 0.4$ billion in gross international reserves despite inflows of some $\$ 1.9$ billion. $^{2}$

5. In June 2009, the authorities gradually adjusted the rubel against the basket bringing the REER closer to its pre-crisis level, widened the exchange rate band and tightened market interest rates. The exchange rate was gradually depreciated against the central parity of the basket by 5 percent (reducing the REER to the level of August 2008) and the band was widened from \pm 5 percent to \pm 10 percent to provide a buffer against the shocks. In order to revert the process of currency substitution, the NBRB pursued policies aimed at increasing the spread between domestic and foreign currency deposit interest rates. Currency substitution came to a halt and has been partially reversed since June, but overall pressure on reserves continued, with net international reserves falling (excluding the SDR allocation in the end of August) by $\$ 0.76$ billion in the period from July to August 2009.

6. It should be noted, however, that the exchange rate pressures critically depend on the domestic demand policies pursued by the authorities. To the large extent, the expansion of the current account deficit in 2008 could be attributed to the widening of the gap between the domestic demand in Belarus and that of its trading partners. Whereas during 2004-07 Belarus domestic demand exceeded that of the trading partners by an average 4.5 percent, in 2008 the gap increased to 9.5 percent. Domestic demand has continued to be bolstered in 2009, with fixed asset investment expanding by over 17 percent in the first half of 2009, due mainly to vigorous lending under government programs and support of state-owned enterprises.

\footnotetext{
${ }^{2}$ The inflows are as follows: $\$ 800$ from the IMF tranche, $\$ 500$ from bilateral borrowing and $\$ 625$ from privatization proceeds.
} 


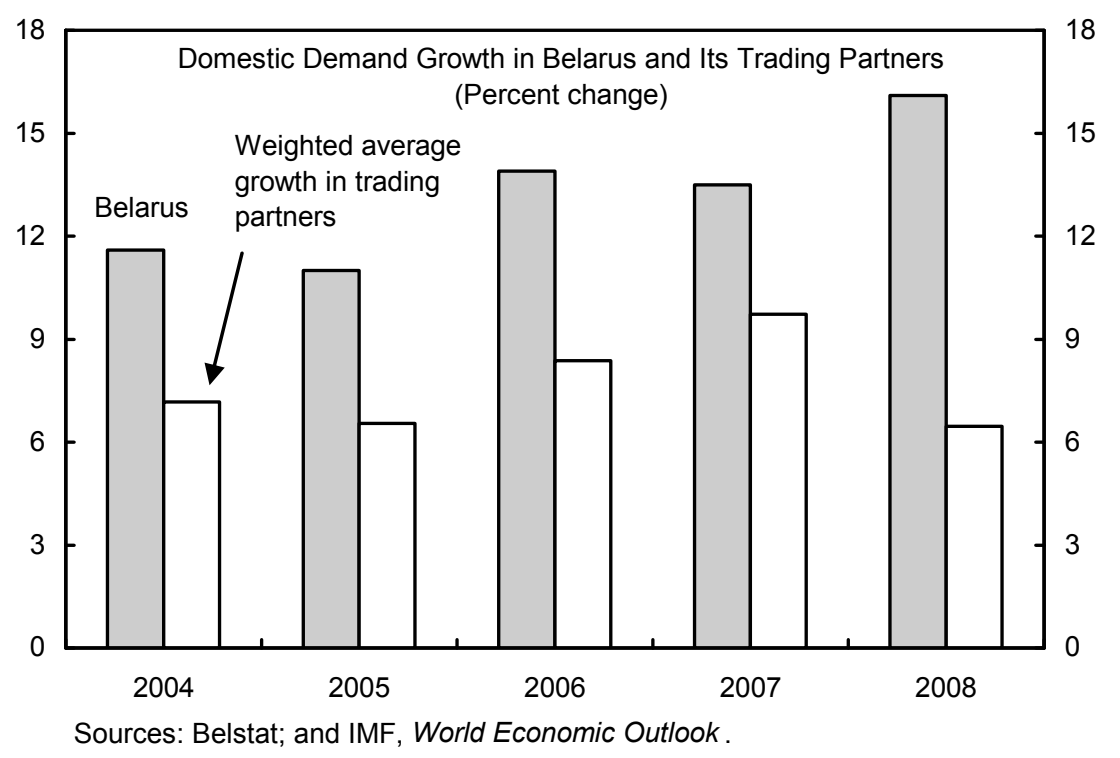

7. In the case of Belarus, assessing the need for further adjustment of the exchange rate is a challenging task:

- $\quad$ The equilibrium exchange rate critically depends on domestic polices (e.g. looser monetary policy is consistent with a relatively depreciated exchange rate). Therefore, one needs to make a judgment regarding the current state of policies in order to estimate the "underlying" (structural) current account deficit that would persist if the effects of temporary shocks were washed out. In this paper, it is assumed that the authorities will follow the tight domestic demand policies agreed in the Letter of Intent for the second review of the Stand-By Arrangement (SBA).

In addition, there is considerable uncertainty about the effectiveness of exchange rate adjustment in an economy with strong features of central planning. The strong role of the state in allocating resources could weaken the expenditure-switching role of exchange rate policy relative to more market-based economies. Widespread practice of quantitative targeting, ranging from economy-wide targets (e.g. growth, fixed investment, inflation and credit growth), to micro-level quantitative targets given to key industrial enterprises remains a distinctive feature of Belarus. Quantitative targets and the soft budget constraints arising from the active role of the state in the financial sector may frustrate the price mechanism: profitable enterprises do not necessarily have an incentive to increase production beyond their "targets" whereas loss-makers may continue operating (which is illustrated by the increase of inventories in the first half of 2009 to about 95 percent of average monthly production from 50 percent a year earlier). These rigidities increase the exchange rate adjustment required to 
achieve a given correction of the current account relative to economies with more market-oriented systems.

These caveats suggest that using estimates of misalignment for designing an adjustment policy package should be done cautiously.

\section{B. Macro Balance Approach}

8. The macro balance approach focuses on a simultaneous achievement of internal and external balance. It has two essential components: the underlying current account associated with positions of internal balance in all trading partners (schedule UCA(REER) on the figure below) and the equilibrium level of savings-investment balance that is assumed to be independent of the exchange rate $(\mathrm{S}-\mathrm{I})_{\mathrm{E}}$. The negatively-sloped UCA schedule shows a reduced-form relationship between the underlying current account and the REER: each point on that line corresponds to an internal balance in the economy as well as its trading partners. As an appreciation of the REER generally worsens the balance, the UCA schedule has a negative slope.

\section{An external equilibrium is depicted by the "fundamental" savings-investment}

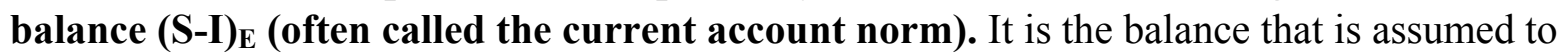
be independent of the real exchange rate and depends on the fundamental characteristics of the economy such as its level of development, population structure, etc. If the underlying current account deviates from the norm (e.g. REER is equal to $\mathrm{R}_{1}$ ), external factors start exerting downward pressure on the real exchange rate, moving the economy to the equilibrium $R_{\mathrm{e}}$.

Illustrating the Macro Balance Approach

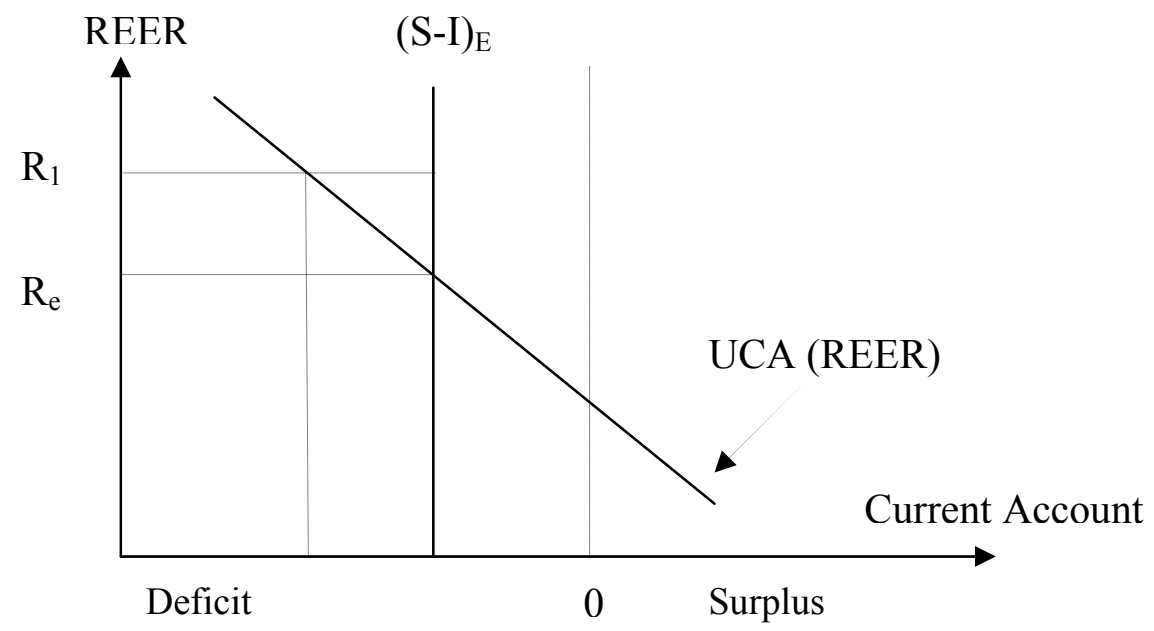


10. What determines the position of the $(\mathrm{S}-\mathrm{I})_{\mathbf{E}}$ schedule? The literature has suggested a number of robust determinants of the savings-investment balance over the medium-term (Lee et al 2008). Examining the channels of transmission from these determinants to the current account balance suggests that all of them should be relevant in Belarus despite its particular economic structure.

- Level of economic development. Less-developed economies have relatively larger investment needs and therefore should run a current account deficit. This has direct relevance to Belarus - the economy is in the early stages of transition and can benefit from further upgrading its capital stock, thereby justifying the need to run current account deficits.

- $\quad$ Fiscal balance. A higher government deficit lowers national savings and therefore contributes to the current account deficit. Thus, an economy with a higher government deficit is expected to run a higher current account deficit over the medium term. The only case when this effect would not work is when private sector would offset a reduction in public savings (i.e. the case of Ricardian equivalence) However, given the relatively closed financial account for the non-government sectors of the economy, this effect should be applicable to Belarus.

- Demographics. A higher share of economically active population should increase national savings and therefore improve the current account balance. This effect should hold in Belarus regardless of the central planning features of the economy.

- $\quad$ Net foreign assets. Whereas the theoretical effect of Net External Asset Position (NEAP) on the current account is ambiguous, countries with higher NEAP tend to attract higher income from their foreign position thereby creating a positive association between NEAP and current account. This should be directly applicable to Belarus - as the economy accumulates liabilities, its debt payments should increase as percentage of GDP.

- Energy balance. Higher oil prices decrease the balance of oil-importing countries, thereby creating a negative association between the oil balance and the current account. Again, this has direct applicability in Belarus given its reliance on natural gas and oil.

- Output growth. Among countries at a similar level of economic development, stronger growth relative to trading partners should be associated with a lower current account balance. 
11. This assessment takes advantage of the pooled regression results used in the Fund's CGER exercise. There are two specifications. The first utilizes all regressors described above, and the second replaces the initial level of net foreign assets with a lagged value of the current account.

\section{In order to assure the "sustainability" of the current account norm, the norm} must be calculated using sustainable values of regressors. Therefore, baseline mediumterm projections were used for fiscal balance, demographics, oil balance and per capita growth. The four-year average current account balance was used for the lagged current account in the hybrid model, and a NEAP value of 30 percent of GDP (observed at the end of the first quarter of 2009) was used in the pooled estimation model. Consistently with the approach used in CGER exercise, the fiscal balance, demographics variables and the per capita growth rate were expressed as deviations from trading partners' averages. The pooled estimation model suggests a norm of -2 percent of GDP whereas the hybrid pooled models yields a norm of -2.7 percent of GDP. The derivation of sustainable values of regressors as well as contributions to the calculated norm are illustrated in Table 1.

\section{The final step of the assessment calculates an appropriate adjustment of the} REER that would close the gap between the underlying current account and the corresponding benchmark found above. Under the policies agreed in the second review of the SBA, the underlying (i.e. structural) current account deficit is judged to be close to 3.5 percent of GDP. Given the long-run elasticities of export and import volumes $\left(e_{X}, e_{M}\right)$, the overall response of the CA balance to one-percent increase in REER can be found as follows:

$e_{C A}=e_{X} \cdot \frac{X}{Y}-\left(e_{M}-1\right) \cdot \frac{M}{Y}$,

where the first term reflects the effect of a change in REER on exports, which, assuming no change in export prices, works through export volumes. The second term reflects the effect on imports via both volume effect $\left(e_{M}{ }^{*} \mathrm{M} / \mathrm{Y}\right)$ as well as the price effect $(\mathrm{M} / \mathrm{Y})$. Applying a long-run export elasticity of -0.71 and an import elasticity of 0.92 (which are the values used in the CGER assessments), the overall current account elasticity is -0.38 . This implies that a 10 percent appreciation in REER would worsen the current account by 3.8 percent of GDP. It should be noted, however, that the elasticities in Belarus could be lower given the rigidities discussed in paragraph 7. Therefore, the adjustment required to bring the UCA to the norm could be higher. 
Current Account Norms

\begin{tabular}{|c|c|c|c|c|c|}
\hline & Coefficient $1 /$ & Belarus values & $\begin{array}{l}\text { Trading partner } \\
\text { values }\end{array}$ & $\begin{array}{l}\text { Sustainable } \\
\text { values of } \\
\text { regressors }\end{array}$ & $\begin{array}{l}\text { Contributons to } \\
\text { the CA norm }\end{array}$ \\
\hline \multicolumn{6}{|c|}{ I. CGER Pooled estimation model } \\
\hline Fiscal balance & $0.20^{* * *}$ & -0.015 & -0.038 & 0.023 & 0.46 \\
\hline Old-age dependency & $-0.14 * *$ & 0.265 & 0.305 & -0.040 & 0.57 \\
\hline Population growth & $-1.21 * * *$ & -0.005 & 0.000 & -0.0045 & 0.54 \\
\hline NEAP & $0.02 * * *$ & -0.301 & $\ldots$ & -0.301 & -0.74 \\
\hline Oil balance & $0.23^{* * *}$ & -0.024 & $\ldots$ & -0.024 & -0.55 \\
\hline Output growth & $-0.21 * *$ & 0.070 & 0.0439 & 0.0260 & -0.54 \\
\hline Relative income 2/ & $0.024 *$ & 16,108 & 52,393 & -0.69 & -1.68 \\
\hline Constant & -0.001 & & & & -0.11 \\
\hline Current account norm & & & & & -2.05 \\
\hline \multicolumn{6}{|c|}{ II. CGER Hybrid Pooled Estimation Model } \\
\hline Fiscal balance & $0.19 * * *$ & -0.015 & -0.0382 & 0.023 & 0.43 \\
\hline Old-age dependency & $-0.12 * *$ & 0.265 & 0.3045 & -0.040 & 0.50 \\
\hline Population growth & $-1.03 * *$ & -0.005 & -0.0004 & -0.0045 & 0.46 \\
\hline Lagged current account $3 /$ & $0.37 * * *$ & -0.044 & $\ldots$ & -0.044 & -1.61 \\
\hline Oil balance & $0.17^{\star * *}$ & -0.024 & & -0.024 & -0.40 \\
\hline Output growth & $-0.16 *$ & 0.070 & 0.0439 & 0.0260 & -0.41 \\
\hline Relative income & 0.020 * & 16,108 & 52,393 & -0.69 & -1.35 \\
\hline Constant & -0.003 & & & & -0.31 \\
\hline Current account norm & & & & & -2.70 \\
\hline
\end{tabular}

Source: Lee et al (2008).

$1 /{ }^{*},{ }^{* *}$, and ${ }^{* * *}$ indicate significance at the 10,5 , and 1 percent level, respectively.

2/ Sustainable value is calculated as GDP_PPP(BLR)/GDP_PPP(US)-1

$3 /$ Average current account balance for 4 years.

\section{Both pooled estimation and hybrid pooled estimation models suggest that, under} the baseline policies, there is no clear evidence that the exchange rate is substantially overvalued. Based on the underlying current account of 3.5 percent and the elasticity of 0.38 , the models suggest an overvaluation of $2-4$ percent, depending on the model specification. Given the large margins of error (including the fact that panel estimation was performed on a set of industrialized and large emerging market economies), results below 5 percent should not be used as evidence that exchange rate is substantially overvalued. Thus, the current exchange rate-perhaps with a small real depreciation within the current exchange rate band — could be considered sustainable.

Macroeconomic Balance Approach

\begin{tabular}{|c|c|c|c|c|c|}
\hline & $\begin{array}{l}\text { CA norm } \\
\text { (percent of } \\
\text { GDP) }\end{array}$ & $\begin{array}{l}\text { Underlying CA } \\
\text { (percent of } \\
\text { GDP) }\end{array}$ & Gap & $\begin{array}{l}\text { REER } \\
\text { elasticity }\end{array}$ & Misalignment \\
\hline & \multicolumn{5}{|c|}{ Baseline scenario (policies consistent with the Letter of Intent) } \\
\hline I. CGER Pooled estimation model & -2.1 & -3.5 & -1.4 & -0.38 & 3.8 \\
\hline \multirow[t]{2}{*}{ II. CGER Hybrid Poolded Estimation model } & -2.7 & -3.5 & -0.8 & -0.38 & 2.1 \\
\hline & \multicolumn{5}{|c|}{ Persistent current account deficit scenario } \\
\hline I. CGER Pooled estimation model & -2.1 & -9.6 & -7.6 & -0.38 & 20.0 \\
\hline II. CGER Hybrid Poolded Estimation model & -2.7 & -9.6 & -6.9 & -0.38 & 18.3 \\
\hline
\end{tabular}

Source: IMF staff calculations. 
15. For illustrative purposes, misalignment is also calculated for a scenario in which the current account deficit fails to adjust over the medium term and broadly remains at its expected level in 2009. The result suggests that a 18-20 real depreciation would be needed to bring the current account to its medium-term norm.

\section{External Sustainability Approach}

16. This approach checks whether external sector dynamics are consistent with stability of the NEAP. As the macroeconomic balance approach relies on many components prone to margins of error (underlying current account, elasticity, current account norms), it is instructive to cross-check the results with the external sustainability approach. This approach does not depend on behavioral assumptions and therefore can be applied equally to any type of economy. The approach checks the consistency of the current account with a given ("benchmark") NEAP using a simple intertemporal budget constraint which states that change in the net foreign asset position $\left(N E A P_{t}-N E A P_{t-1}\right)$ is equal to the current account balance $\left(\mathrm{CA}_{\mathrm{t}}\right)$ plus the capital gains $\left(\mathrm{KG}_{\mathrm{t}}\right)$ as well as any capital transfers and remaining wedges between the current accounts and net financial flows $\left(\mathrm{E}_{\mathrm{t}}\right)$ :

$N E A P_{t}-N E A P_{t-1}=C A_{t}+K G_{t}+E_{t}$

17. Abstracting from $\mathbf{K G}_{\mathbf{t}}$ and $\mathbf{E}_{\mathbf{t}}$ (which is a reasonable assumption in Belarus given the low level of capital transfers and the limited scope for valuation changes), and expressing $\mathrm{CA}_{t}$ and the NEAP as percentages of GDP yields the following budget constraint:

$$
b_{t}-\frac{b_{t-1}}{(1+g)(1+\pi)}=c a_{t}
$$

where $b_{t}$ and $b_{t-1}$, and $c a_{t}$ are NEAP and CA expressed in percentages of GDP and $(1+\mathrm{g})(1+\pi)$ is the economy's nominal growth rate. Thus, the current account balance consistent with the non-changing NEAP measured as a percent of GDP $(b s)$ is found as follows:

$c a_{S}=\frac{g+\pi \cdot(1+g)}{(1+g) \cdot(1+\pi)} b_{S}$

18. Thus, the NEAP-stabilizing current account $c a_{s}$ is proportional to $b_{s}$ with the slope depending on the medium-term values of real growth and inflation. The mediumterm values of these variables are projected taking into account the established (most likely to be implemented) policies. Given the NEAP value of minus 31 percent of GDP (the level observed in the end of the first quarter of 2009) the NEAP-stabilizing current account deficit in Belarus is 3.6 percent and the resulting misalignment of the exchange rate is zero. Thus, in the framework of the external sustainability approach, the underlying current account is consistent with maintaining a constant NEAP position. 
External Sustainability Approach

\begin{tabular}{|c|c|c|c|c|c|c|c|c|}
\hline & $\begin{array}{c}\text { NEAP } \\
\text { (percent of } \\
\text { GDP) }\end{array}$ & $\begin{array}{l}\text { Real growth } \\
\text { (percent) }\end{array}$ & $\begin{array}{l}\text { Inflation } \\
\text { (percent) }\end{array}$ & $\begin{array}{c}\text { NEAP- } \\
\text { stabilizing } \\
\text { CAB } \\
\text { (percent of } \\
\text { GDP) }\end{array}$ & $\begin{array}{l}\text { Underlying } \\
\text { CAB } \\
\text { (percent of } \\
\text { GDP) }\end{array}$ & $\begin{array}{c}\text { Gap } \\
\text { (percent of } \\
\text { GDP) }\end{array}$ & $\begin{array}{l}\text { REER } \\
\text { elasticity }\end{array}$ & $\begin{array}{l}\text { Misalign. } \\
\text { (percent) }\end{array}$ \\
\hline & \multicolumn{8}{|c|}{ Baseline scenario } \\
\hline Stabilizing the current level of NEAP 1/ & -30.8 & 7.0 & 6.0 & -3.6 & -3.5 & 0.1 & -0.4 & -0.4 \\
\hline \multirow[t]{2}{*}{ No adjustment of the underlying CA } & -29.6 & 7.0 & 6.0 & -3.5 & -3.5 & 0.0 & -0.4 & 0.0 \\
\hline & \multicolumn{8}{|c|}{ Persistent current account deficit scenario } \\
\hline Stabilizing the current level of NEAP 1/ & -30.8 & 4.8 & 8.7 & -3.8 & -9.6 & -5.9 & -0.4 & 15.5 \\
\hline No adjustment of the underlying CA & -78.9 & 4.8 & 8.7 & -9.6 & -9.6 & 0.0 & -0.4 & 0.0 \\
\hline
\end{tabular}

Source: IMF staff calculations.

$1 /$ NEAP at the end of 2009Q1.

19. In the illustrative scenario of the persistent current account deficit, the exchange rate misalignment is sizeable. In order to maintain the NEAP at the benchmark level, the REER would need to depreciate by close to 15 percent in order to drive the current account deficit to its NEAP-stabilizing level. If the current account does not adjust, the NEAP is likely to grow to nearly minus 80 percent of GDP, raising doubts about its sustainability.

\section{Concluding Remarks}

20. The answer to a question whether a further correction of the exchange rate is needed is affected by the domestic policies pursued by the authorities. The disparity between the domestic demand in Belarus and its trading partners observed in 2008 and also during the first half of this year fueled the demand for imports and produced strong pressures on the exchange rate. If the domestic demand differential between Belarus and its trading partners is lowered as envisaged under the Fund program and maintained at a prudent level over the medium term, the current exchange rate-perhaps with a small additional correction within the current exchange rate band — could be maintained.

\section{The external financing obtained in $\mathbf{2 0 0 9}$ has allowed Belarus to mitigate the} worst effects of the global crisis, but reliance on external financing to support domestic demand is unsustainable over the medium term. The support of domestic demand through government lending programs and other measures prevented sharp adjustment in the real sector - enterprises escaped shutting down their production and massive lay-offs were avoided. However, it would be difficult to maintain this approach for long if the effects of the crisis on Belarus' trading partners, most notably Russia, prove to be persistent. In order to regain sustainability, the authorities should address the underlying cause of domestic demand persistence - the system of incentives based on attaining particular quantitative targets, combined with subsidized lending by state-owned banks, which makes traditional channels of adjustment far less effective than in more market-based economies. If the structural rigidities are not moderated, there is a considerable risk of being trapped in the "persistent current account deficit" scenario which would either require exiting the peg or introducing exchange restrictions when international reserves fall to a dangerously low level. 


\section{References}

Isard, P., 2007, "Equilibrium Exchange Rates: Assessment Methodologies," IMF Working Paper No. 07/296 (Washington: International Monetary Fund).

IMF, 2006, Methodology for CGER Exchange Rate Assessments, Research Department, November (Washington).

,2007, "Review of the1977 Decision-Proposal for a New Decision-Companion Paper," Washington, $D C$, available from: http://www.imf.org/external/np/pp/2007/eng/nd.pdf.

Lee, J., G.M. Milesi-Ferretti, Jonathan Ostry, Alessandro Prati, and Luca Antonio Ricci, 2008, "Exchange Rate Assessments: CGER Methodologies," IMF Occasional Paper No.261 (Washington: International Monetary Fund).

Lipschitz, L., and D. McDonald,1992, "Real Exchange Rate and Competitiveness: A Clarification of Concepts, and Some Measurements for Europe," Empirica-Austrian Economic Papers, Vol.19, No.1. 


\section{Sources of Recent Growth ANd Prospects For Future Growth ${ }^{1}$}

1. Belarus achieved impressive economic growth in the past decade, averaging 7.5 percent per year. Compared with other CIS countries, growth performance in Belarus has also been less volatile. The benefits from the recent growth appeared to be fairly broadly shared by the population, as the poverty rate declined from 47 percent in 1999 to 6 percent in 2008, and inequality remained moderate. In addition, the country ranked the highest among the CIS countries in the 2008 UNDP human development indices. ${ }^{2}$

2. However, there have been repeated predictions from outside observers, including the IMF staff, ${ }^{3}$ that Belarus's economic model

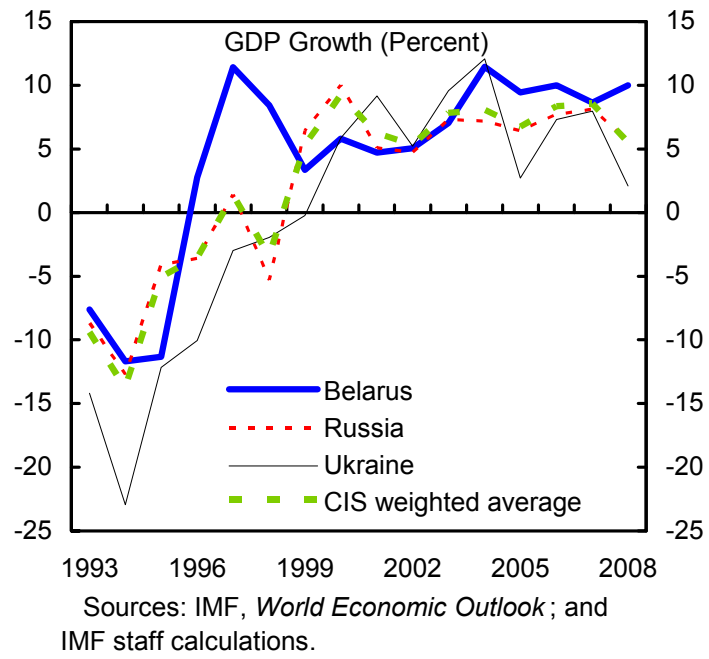
is ultimately unsustainable in the absence of policy adjustment and wide-ranging structural reforms. Given its slow progress in transition to a market economy as indicated in the EBRD's transition indicators, the growth model in Belarus is sometimes described as a puzzle.

\footnotetext{
${ }^{1}$ Prepared by Shuang Ding, with input from Dmitriy Kovtun, Abdoul Wane, and Pritha Mitra.

${ }^{2}$ The Human development index (HDI) looks beyond GDP to a broader definition of well-being. It provides a composite measure of three dimensions of human development: living a long and healthy life (measured by life expectancy), being educated (measured by adult literacy and enrolment at the primary, secondary and tertiary levels), and having a decent standard of living (measured by GDP per capita at purchasing power parity).
}

${ }^{3}$ See Republic of Belarus: Selected Issues, IMF Country Report No. 05/217, June 2005. 


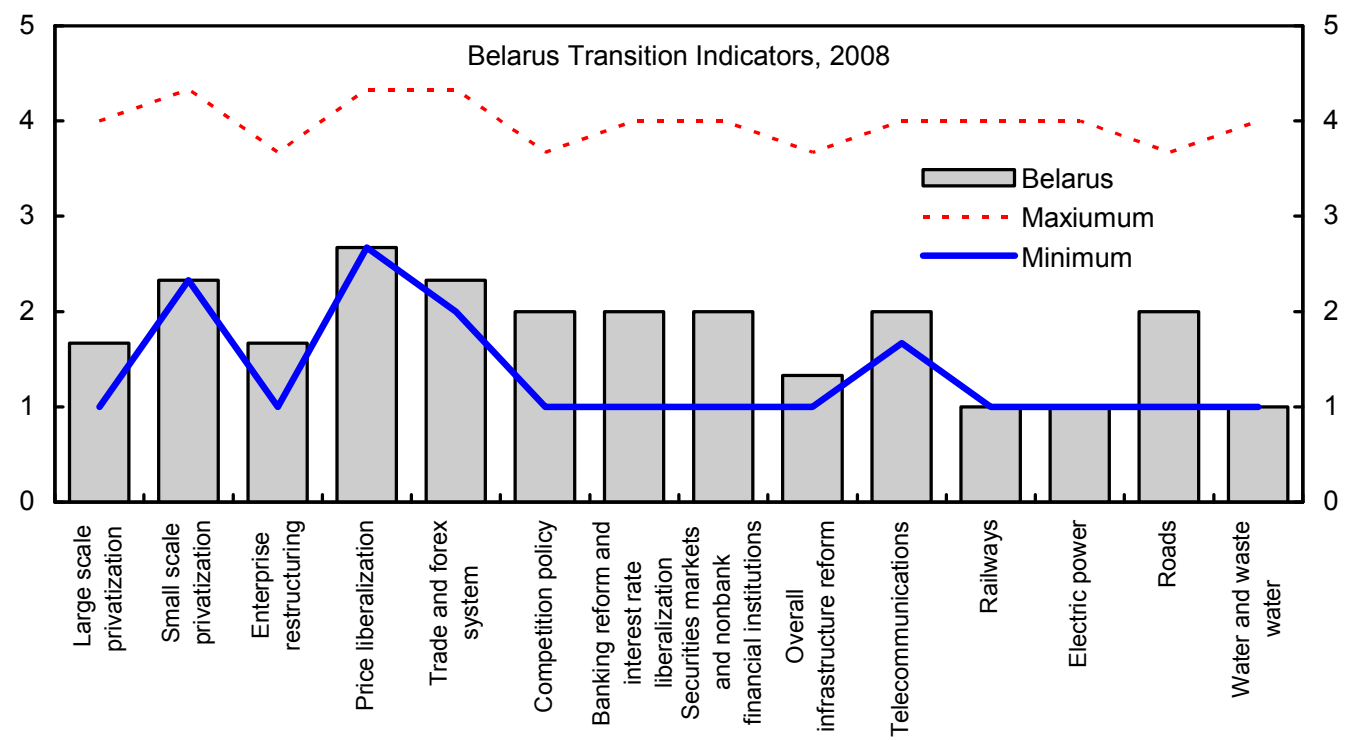

Source: EBRD, Transition Report, 2008.

3. This paper attempts to identify factors underlying Belarus's remarkable economic growth in recent years, and shed light on how to sustain rapid growth in the post-crisis period. Section A analyzes Belarus's growth factors from both the supply and demand sides, based on stylized facts. Section B discusses the results of the growth accounting exercise. Section C estimates Belarus's potential growth in light of some external and domestic constraints on growth. Section D discusses structural reforms that can ease constraints on growth. Section E concludes.

\section{A. Overview of Growth Factors}

\section{Supply Side}

4. Belarus's rapid growth can be explained by the growth factors in a standard production function:

Capital stock. Belarus inherited a quite valuable capital stock from the former Soviet Union, including assets in the automobile and tractor industries that remain competitive in the CIS market and chemical and oil processing industries that can compete in the European markets. Since independence, Belarus has managed to avoid the large-scale asset stripping that took place in other CIS countries, and has increased its capital stock by keeping high investment ratios. 
Investment Activity, 2001-08

(Percent)

\begin{tabular}{lcccccccc}
\hline & 2001 & 2002 & 2003 & 2004 & 2005 & 2006 & 2007 & 2008 \\
\hline $\begin{array}{l}\text { Investment to GDP ratio } \\
\text { Belarus }\end{array}$ & 24.4 & 23.2 & 25.3 & 29.5 & 26.5 & 33.5 & 35.9 & 35.8 \\
$\quad$ Russia & 21.9 & 20.1 & 20.8 & 20.9 & 20.1 & 21.4 & 24.3 & 25.5 \\
Ukraine & 21.8 & 20.2 & 22.0 & 21.2 & 22.6 & 24.8 & 28.2 & 28.5 \\
Average for peer countries 1/ & 22.4 & 22.7 & 25.0 & 26.6 & 26.7 & 26.2 & 28.4 & 27.0 \\
\hline
\end{tabular}

Sources: IMF, World Economic Outlook; and IMF staff calculations.

1/ Includes Armenia, Azerbaijan, Belarus, Georgia, Kazakhstan, Kyrgyz Republic, Moldova, Russia, Tajikistan, Ukraine, and Uzbekistan.

- Labor. Belarus has a well-educated and disciplined labor force. Compared with some other CIS countries, labor outflow has been less significant. The economically active population in the country declined slowly between 1995-2005 (0.2 percent annually), but has rebounded since 2005, which may have reflected a reflow of workers seeking job opportunities in a booming economy.

Capacity utilization. It appears both capital and labor have been utilized at very high rate, owing in part to ambitious quantitative targeting. The unemployment rate has been consistently low and declining. Capacity has at times been stretched, as indicated by the pick up in inflation since 2007.

- $\quad$ Productivity. Labor productivity has been growing faster than its CIS peers for most of the period, benefiting from the high quality labor and an increasing capital stock. Improvement in energy efficiency also played an important role in improving total factor productivity. ${ }^{4}$

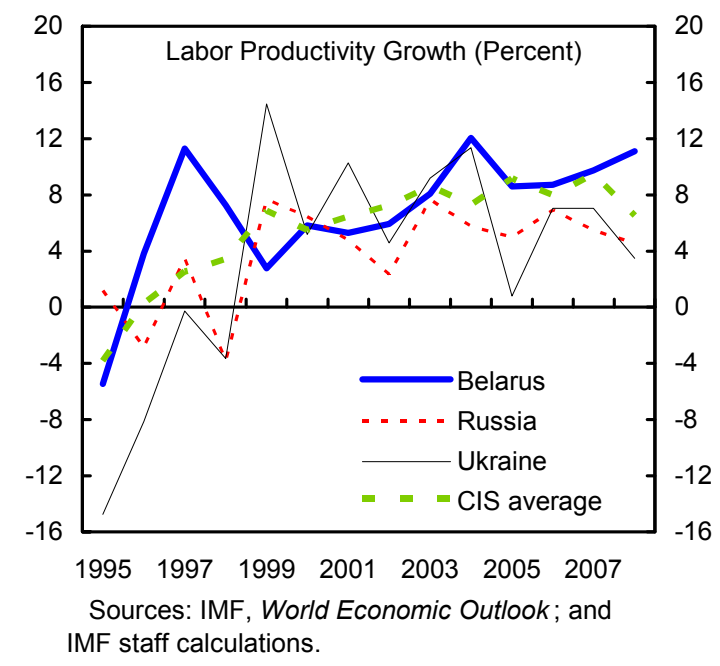

\footnotetext{
${ }^{4}$ Supported by government policies, energy intensity, as measured by tons of oil equivalent to produce US\$1,000 of GDP adjusted by PPP went down from 0.76 in 1995 to 0.45 in 2004.
} 


\section{Demand Side}

5. Belarus has managed to realize its growth potential, thanks to a generally favorable external environment and domestic policies that increased demand for its products. During 2001-04, domestic and external demand contributions to growth were broadly balanced. After 2005, growth was boosted mainly by domestic consumption and investment, and current account balance deteriorated. Belarus was able to fill the gap between saving and investment by tapping external financing, thereby sustaining high growth.

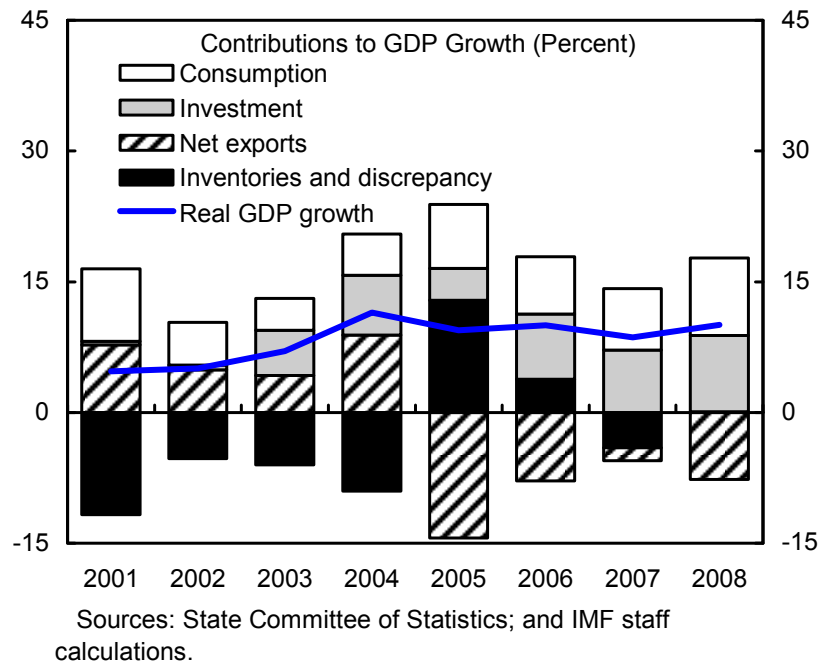

Contributions to Growth, 2001-08

(Percent)

\begin{tabular}{lrrrrrrrr}
\hline & 2001 & 2002 & 2003 & 2004 & 2005 & 2006 & 2007 & 2008 \\
\hline GDP growth & 4.7 & 5.0 & 7.0 & 11.4 & 9.4 & 10.0 & 8.6 & 10.0 \\
Consumption & 8.3 & 4.9 & 3.7 & 4.7 & 7.3 & 6.6 & 7.0 & 8.9 \\
Investment & -0.5 & 1.3 & 4.1 & 4.5 & 4.7 & 7.0 & 6.4 & 7.9 \\
Net exports & 7.8 & 4.9 & 4.2 & 8.9 & -14.4 & -7.9 & -1.5 & -7.7 \\
Inventories and discrepancy & -10.9 & -6.1 & -5.0 & -6.6 & 11.8 & 4.3 & -3.3 & 1.0 \\
\hline
\end{tabular}

Sources: Belstat; and IMF staff calculations.

- $\quad$ Although the contribution of net exports was mostly negative, the positive influence of gross exports on growth should not be underestimated in the sense that it prevented even larger trade deficit. Exports have benefited from vibrant growth in Russia and the world in general, especially since 2003. ${ }^{5}$ Belarus enjoys strong integration of production chains with those of the Russian economy, as well as easy access to the Russian market. The boom in Russia created a powerful boost for Belarus's non-oil exports which were traditionally designed and produced for the Russian markets. Energy subsidies from Russia made Belarus's oil product exports to Europe more

\footnotetext{
${ }^{5}$ World GDP growth had been above 3 percent per year since 2003 until the current economic crisis; Russia's economy grew by 6-8 percent per year during the same period.
} 
profitable. ${ }^{6}$ The resulting improvement in terms of trade, which tends to accelerate when world oil price rises, not only contributed to oil trade surpluses in recent years, but also produced income and wealth effects that fueled consumption and investment.
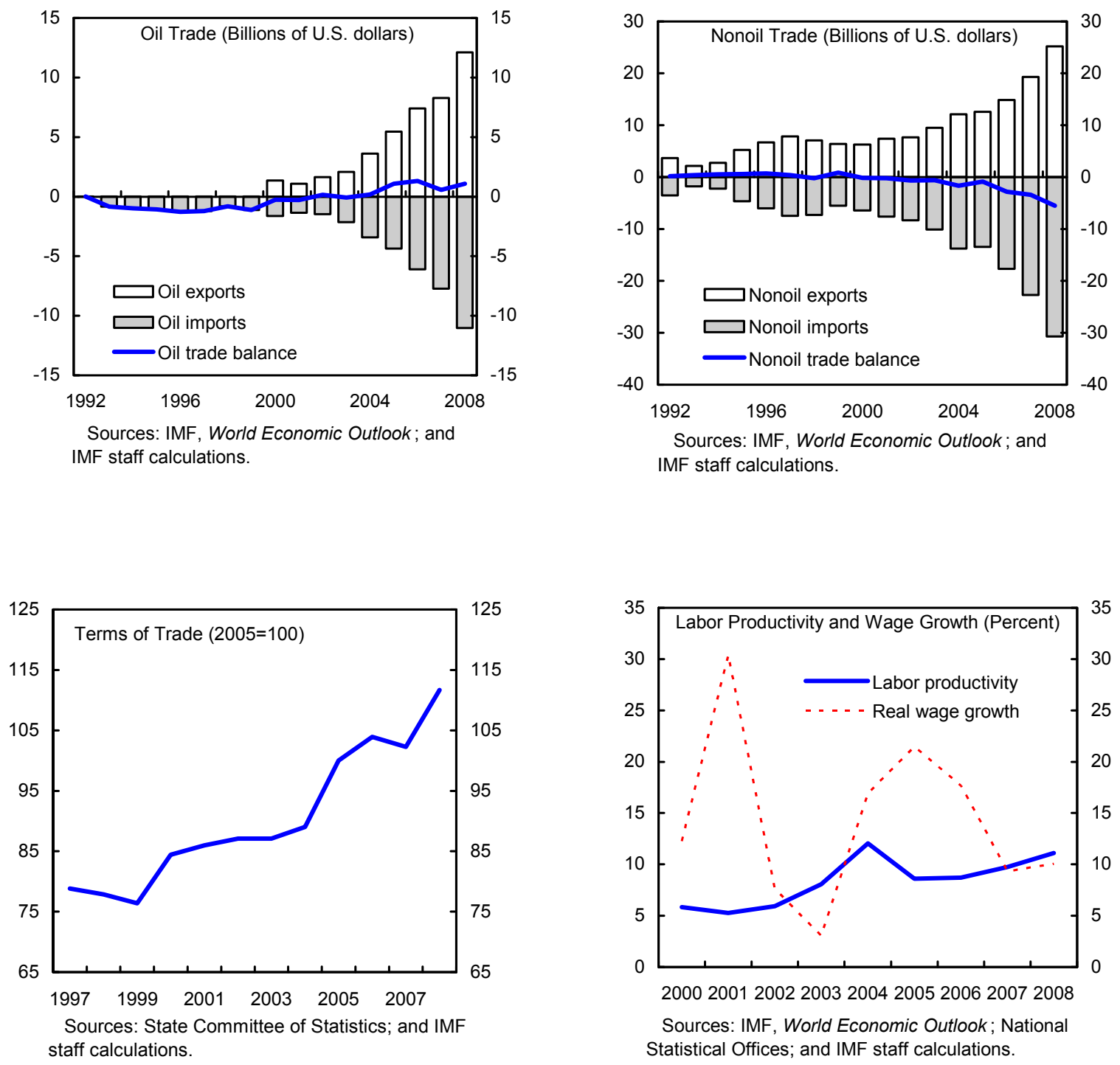

\footnotetext{
${ }^{6}$ Until recently, Belarus had been purchasing energy (crude oil and natural gas) from Russia at Russia's highly subsidized domestic price. The total subsidy on energy imports in recent years is estimated at about $\$ 5.9$ billion in 2007 and $\$ 8.2$ billion in 2008. In the absence of these subsidies, energy import costs would have been higher by about 13 percent of GDP in both 2007 and 2008 .
} 
- $\quad$ Apart from capital expenditure in the budget, state-owned enterprises made substantial investment under government programs. Supported by subsidized lending, household investment in residential apartments is believed to be high. ${ }^{7}$

- $\quad$ Government wage and income policy has contributed to buoyant private consumption. Since 2000, the real wage increase on average has surpassed productivity growth.

\section{B. Sources of Growth From Production Function Approach}

6. The production function approach is often used to assess the sources of economic growth and estimate potential growth. The production function describes a functional relationship between output and factor inputs. Output is at its potential if the rates of capacity utilization are normal, i.e., labor input is consistent with the natural rate of unemployment and technological progress is at its trend level. In a standard Cobb-Douglas production function, output depends on labor, capital, and total factor productivity (TFP): ${ }^{8}$

$$
\begin{gathered}
Y=A L^{\alpha} K^{\beta} \\
y=a+\alpha l+\beta k
\end{gathered}
$$

where $Y$ is real GDP, $A$ is TFP, $L$ is total employment, $K$ is the capital stock, $\alpha$ is the labor elasticity of output, and $\beta$ is the capital elasticity of output. Variables in lower case are in logs.

7. Neither A nor $\alpha$ and $\beta$ can be directly observed. Under perfect competition, $\alpha$ corresponds to the share of labor income in GDP. Under the assumption of constant returns to scale, ${ }^{9} \alpha+\beta=1$, and capital income share $\beta=1-\alpha$. Substituting these parameters into the production function, a residual can be derived:

$$
\text { Solow residual }=y-\alpha l-\beta k
$$

8. Due to economic cycles, the Solow residual includes the effects of TFP and the cyclical components in actual output. TFP can be derived through filtering or by regression on a set of variables that are sources of TFP growth.

\footnotetext{
${ }^{7}$ Preferential loans have been provided to individual citizens since 2000 when the Presidential Decree No. 185 was adopted.

${ }^{8}$ TFP is a variable that accounts for effects in total output not caused by inputs. Technology growth and efficiency improvements are regarded as two of the biggest sub-sections of TFP.

${ }^{9}$ A doubling of input will lead to a doubling of output.
} 
9. For Belarus, the production function is applied to actual data during 1995-2008 to derive TFP. Real GDP and total employment data are from the National Statistical Committee. Capital stock series are constructed using the perpetual inventory method, assuming a constant depreciation rate of 5 percent. ${ }^{10}$ The labor share $\alpha$ and capital share $\beta$ are 0.45 and 0.55 , respectively. ${ }^{11}$

10. The result shows that during 2001-08 Belarus registered an average growth rate of 8.3 percent, of which factor accumulation explained about 70 percent, while productivity gains made a smaller but also substantial contribution (23 percent). Within factor accumulation, the growth of capital stock - supported by high investment-to-GDP ratiosplayed a dominant role since the growth of labor stagnated.

Sources of Economic Growth

(Percent)

\begin{tabular}{lrr}
\hline & & \\
& 1995-2000 & 2001-08 \\
\hline Real GDP growth & & \\
Factor accumulation 1/ & 3.4 & 8.3 \\
Labor & 6.3 & 6.1 \\
Capital & -0.9 & 0.4 \\
Solow residual 2/ & 12.3 & 10.7 \\
Total factor productivity & -2.9 & 2.2 \\
Cyclical factors & -0.7 & 1.9 \\
\hline
\end{tabular}

Sources: Belarusian authorities; and IMF staff estimates.

$1 /$ Accumulation of labor and capital, using factor shares of 0.45 and 0.55 respectively.

2/ Residual from the growth accounting exercise.

11. Based on the panel on the filtered variables, capital stock growth remained high but exhibited a declining trend, implying a higher investment ratio would be needed to compensate for depreciation and maintain the capital stock growth. TFP growth reached its height during $2002-04$, and has been falling since then.

\footnotetext{
${ }^{10} \mathrm{~K}_{\mathrm{t}}=\mathrm{K}_{\mathrm{t}-1} *\left(1-\delta_{\mathrm{t}}\right)+\mathrm{I}_{\mathrm{t}}$, where $\mathrm{K}$ is capital stock, $\delta$ is depreciation rate, and $\mathrm{I}$ is investment.

${ }^{11}$ Based on data provided by the National Statistical Committee, which are consistent with labor share (0.5) calculated by Oomes and Dynnikova (2006) for Russia, and labor share (0.52) used by Konuki (2008) for Slovakia.
} 

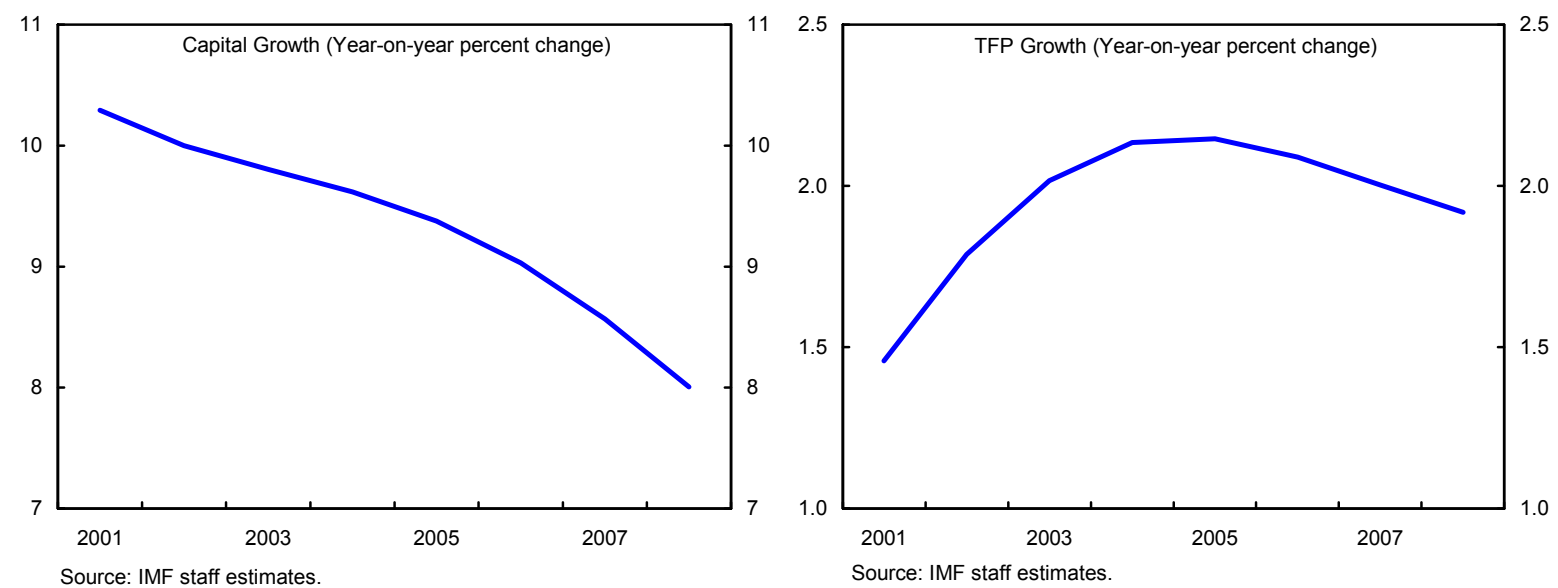

\section{Prospect for Future Growth}

12. Statistical methods are often used to provide a rough estimate of potential output. Estimates based on the Hodrick-Prescott (HP) filter imply an economic overheating in 2008, and that Belarus's potential growth was as high as 8 percent right before the economic crisis. However, the univariate HP filtering, which assumes that output gaps are zero on average during the period in question, has no economic foundations, and therefore should be interpreted with caution.

13. In fact, the result may overstate potential growth since some of the factors which have supported recent rapid growth appear temporary (such as energy subsidies from Russia) and others may not be sustainable (savings and investment imbalance

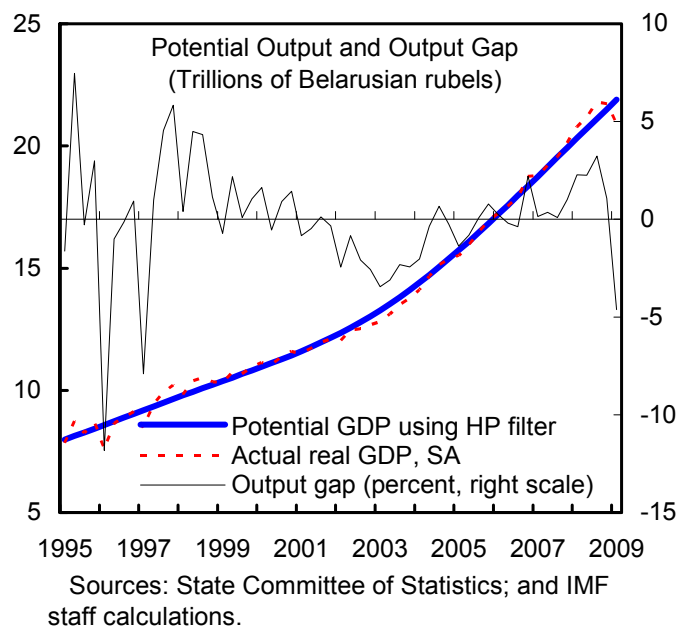
as reflected in the continuous current account deficits).

- $\quad$ Both the GDP levels and potential growth rates of Belarus's main trading partners are likely to be permanently lower in the aftermath of the most severe financial crisis since World War II, reducing external demand for Belarus's products.

- $\quad$ Easy access to the Russian market and financing can no longer be taken for granted, following recent incidents of trade disputes between the two countries and given Russia's open skepticism about Belarus's debt repayment capacity. 
- $\quad$ Russia is also phasing out energy subsidies to Belarus for both oil and gas exports (Box 1). ${ }^{12}$

- Owing to the global financial crisis, attracting external financing to supplement domestic savings would become more difficult or more costly, especially for emerging economies in Eastern Europe. Without major FDI inflows, shortages in external financing may constrain a growth model that relied on external savings to support the high investment ratio.

- Domestically, the returns from high investment appear to have diminished, as shown in a rise in the incremental capitaloutput ratio (ICOR), indicating more investment would be needed to produce an extra unit of output. The recent emphasis on investment in residential construction, which does not contribute directly to building productive capacity, is likely to reduce the investment efficiency further.

- $\quad$ Like some other countries with aging populations, the labor force is likely to shrink reflecting demographic trends.

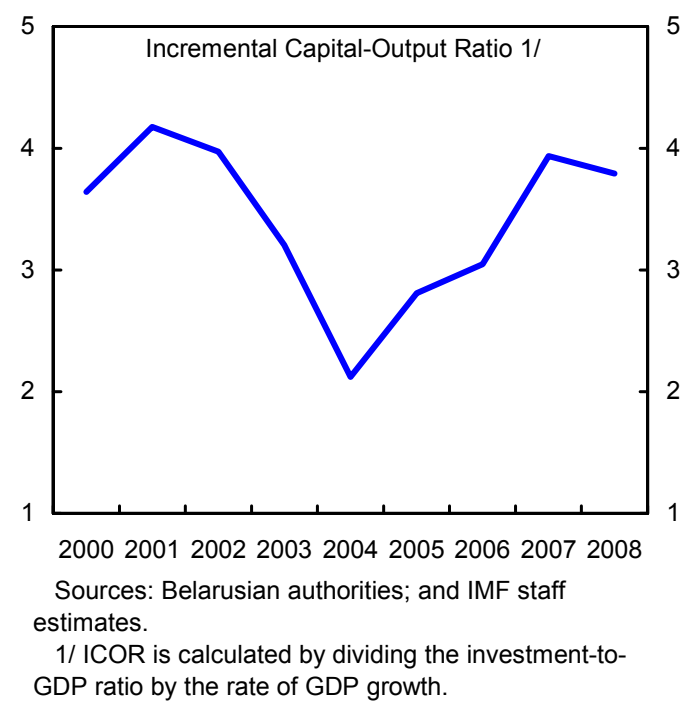

14. The production function approach, which is based on economic theory, makes it possible to estimate potential growth based on estimates on potential employment, capital stock, and productivity growth. To arrive at an estimate of the post-crisis potential growth for Belarus, a few assumptions are made, mostly following recent trends. In particular:

- $\quad$ Employment growth is assumed to be zero in the medium term, reflecting the declining trend of population, and the fact that unemployment rate is already very low, leaving limited room for reducing it further.

\footnotetext{
${ }^{12}$ Russian firms were exempted from paying Russian export duties on the crude oil they supplied to Belarus until early 2007, when Russia imposed export duties on oil shipped to Belarus, and insisted that Belarus charge its own export duty on refined exports to the West. In 2006, the two country also agreed on a path to bring Belarus's gas import price to the level Russia charges to its European customers by 2011 .
} 


\section{Box 1: The Impact of Changing Energy Prices on Belarus's Net Exports}

The contribution of Belarus' oil trade balance to GDP fluctuated with the prices of crude oil and oil products. The net exports of oil, measured as the difference between oil product exports and crude oil imports being processed for exports, increased rapidly during 2005-08, rising from 1 to 3 percent of GDP. The gap between the value of exports and imports widened during this period since crude oil import prices did not rise as rapidly as market prices, reflecting preferential prices received from Russia. The subsidy averaged about 40 percent of the market oil price when prices were rising rapidly. With the recent decline in oil prices, the subsidy declined to about 20 percent of the market oil price.

Looking ahead, the contribution of net oil exports to GDP is expected to return to lower historical levels. As the price of oil has declined from recent highs, net exports will decline to values similar to those during the early 2000s. Negotiations currently underway with Russia may further reduce the subsidy and net export value of oil.

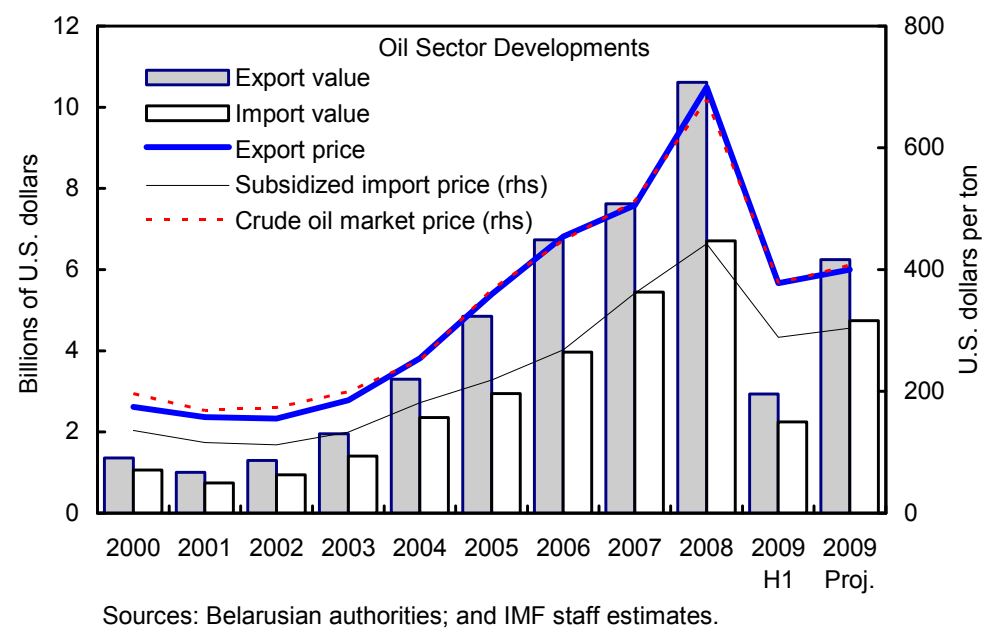

Declining gas subsidies will also negatively impact Belarus' energy trade balance and its contribution to GDP. The price paid by Belarus for its gas imports has risen at a much slower rate than international gas prices. In 2008, Belarus saved almost $\$ 1$ billion on gas imports due to the highly subsidized price it paid to Russia. If the subsidy continues to decline, gas imports will place a heavier burden on the energy trade balance and subsequently GDP, as gas imports increased from $2 \frac{1}{2}$ to $4 \frac{1}{2}$ percent of GDP during 2005-08.

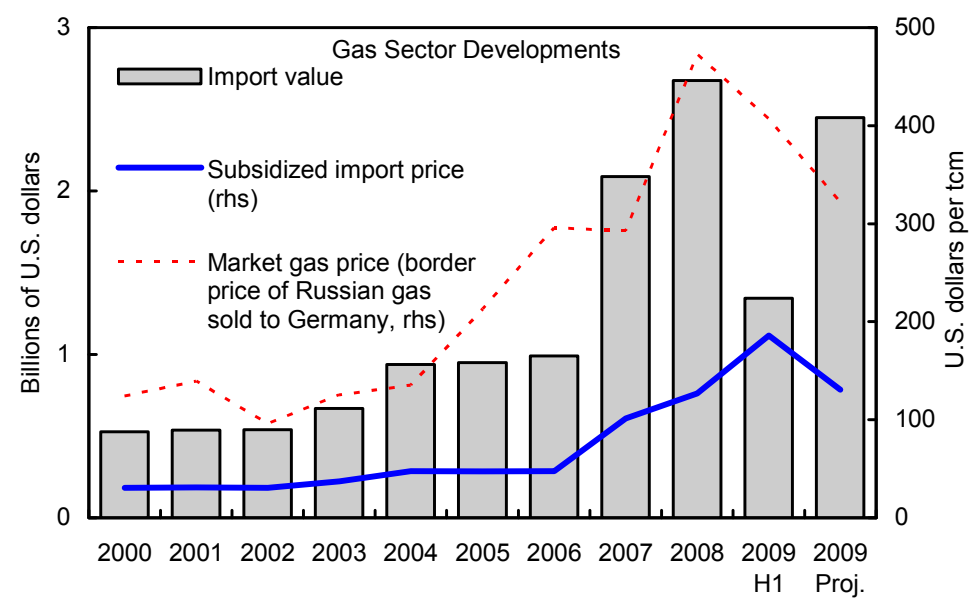

Sources: Belarusian authorities; and IMF staff estimates. 
- $\quad$ Capital stock growth is assumed to fall to about 6.9 percent on average. This reflects the fact that capital stock growth has been slowing down recently despite its high investment ratios.

- $\quad$ TFP is assumed to grow by 1.9 percent at most, reflecting the trend since 2005 , and the declining efficiency of capital investment.

15. Based on these assumptions, medium-term potential growth will reach about 5.7 percent. To repeat its growth rate in the past decade ( $71 \frac{1}{2}$ percent per year), an annual average TFP growth rate of 3.7 percent would be required. In the meantime, the results may err on the side of being optimistic, since the external financing constraints following the current financial crisis are expected to reduce further the growth of investment and capital stock.

Sources of Economic Growth

(Percent)

\begin{tabular}{lrrr}
\hline & 1995-2000 & 2001-08 & $\begin{array}{c}\text { Potential } \\
\text { Growth } \\
\text { Estimate }\end{array}$ \\
\hline Real GDP growth & 3.4 & 8.3 & 5.7 \\
Factor accumulation 1/ & 6.3 & 6.1 & 3.8 \\
Labor & -0.9 & 0.4 & 0.0 \\
Capital & 12.3 & 10.7 & 6.9 \\
Solow residual 2/ & -2.9 & 2.2 & $\ldots$ \\
Total factor productivity & -0.7 & 1.9 & 1.9 \\
Cyclical factors & -2.2 & 0.3 & $\ldots$ \\
\hline
\end{tabular}

Sources: Belarusian authorities; and IMF staff estimates.

$1 /$ Accumulation of labor and capital, using factor shares of 0.45 and 0.55 respectively.

2/ Residual from the growth accounting exercise.

\section{Improving Growth Potential Through Reforms}

16. If the demand and supply constraints discussed in Section $C$ are not addressed, potential growth rate in Belarus could be permanently lower than right before the current crisis. The production function approach indicates that significant productivity gains would be necessary to resume high economic growth given the limited scope to increase capital and labor input significantly. Experience in other countries proves that better allocation of resources, more dynamic private sector, and increased use of foreign capital can help boost productivity growth.

17. Given the authorities' stated preference for the gradualist approach to reforms, China's experience in economic transformation can provide useful insight. A research on 
China's growth performance indicates that while the Chinese economy experienced low productivity growth in the central planning era, productivity became a significant sources of growth since economic reform was introduced in $1978 .{ }^{13}$ Productivity growth contributed 42 percent of the output growth in the reform period of 1979-94, similar to the contribution of capital.

China: Sources of Economic Growth, 1953-94

(Percent)

\begin{tabular}{lrr}
\hline & $1953-78$ & $1979-94$ \\
\hline Output growth & 5.8 & 9.3 \\
Capital input growth & 6.2 & 7.7 \\
Labor input growth & 2.5 & 2.7 \\
Total productivity growth & 1.1 & 3.9 \\
Contribution of capital 1/ & 65.2 & 45.6 \\
Contribution of labor 1/ & 16.8 & 12.8 \\
Contribution of productivity 2/ & 18.0 & 41.6 \\
\hline
\end{tabular}

Sources: State Bureau of Statistics of China, and various Ministries.

1/ Ratio of input growth, weighted by the corresponding factor income share (labor income share is 0.39 for $1953-78$ and 0.45 for 1979-94), to output growth. 2/ Ratio of TFP growth to output growth.

18. Hu and Khan (1996) identified several factors that are related to China's productivity growth in the reform period: (1) reallocation of labor from traditional agriculture to higher value-added activities such as manufacturing; (2) a dramatic rise of the nonstate sector that faced hard budget constraints and had strong profit incentives; (3) China's open-door policy and "special economic zones", which helped attract massive foreign direct investment (FDI); and (4) rapid export growth, which has strong positive correlation with productivity growth in domestic industries based on cross-country studies.

19. For Belarus, the fact that economic transition is still in its early stage augurs well for the potential that can be realized by pursuing market-oriented reforms. Belarus also has an advantage in reinventing its growth model by learning from the experiences and lessons of other countries that have undergone that process. In particular, Belarus has significant room to sustain and boost productivity growth by improving resource allocation and allowing the private sector to play a larger role in production and job creation.

20. To improve resource allocation, state intervention will have to give way to market forces in most areas:

\footnotetext{
${ }^{13} \mathrm{Hu}$ and Khan (1996).
} 
- Price control needs to be reduced to the minimum so that the price mechanism can help adjust excesses and shortages in the economy.

- The labor market needs to be developed and wage control liberalized so that the most dynamic factor of production can flow to areas where it is the most efficient. To achieve that, employment targets for individual enterprises should be removed, and managers should have the discretion to set wages in a way that provides incentives to improve labor productivity.

- Quantitative targets are most useful when the economic structure is relatively simple, and the upstream supply and downstream market are ensured. As Belarus's economy is getting more sophisticated, it will become increasingly difficult to manage it through central planning. In a new environment where easy market access is no longer guaranteed, setting targets at the macroeconomic and enterprise level would make it difficult for enterprises to react to constantly changing market conditions and reduce incentives to improve profitability, leading to inventory accumulation and waste of resources.

- $\quad$ The banking system should be allowed to make lending decisions based on the profitability and risks of the projects. Market-oriented credit allocation would help increase productivity, while government intervention in the form of directed or subsidized lending will create distortions, crowding out lending to the private sector, increasing the vulnerability of the banking system, and potentially imposing a heavy burden on the state budget.

21. Cross-country experience also shows that productivity growth will benefit tremendously from the emergence of a strong and vibrant private sector, and that the benefit can be amplified by the involvement of foreign investors. In this regard, an ambitious and transparent privatization agenda that is open to foreign investors would help bring muchneeded capital, technology, and management skill. This, combined with a high-quality and better-motivated labor force, holds the promise of greatly increasing total factor productivity. Foreign investment can also help diversify Belarus's production base and external market, and spread modern business practices to the rest of the economy. Experience in other countries also underscore the importance of setting up the social safety net and retraining facilities - sometimes by using privatization proceeds - to ease the social impact of temporary increase in unemployment and prepare the labor force for new jobs.

\section{E. Concluding Remarks}

22. Belarus has managed to maintain high growth rates in the past decade, leveraging its inherent strengths but also benefiting from a favorable external environment. Growth outcomes in recent years have consistently beaten forecasts by outsiders, including projections made by the IMF staff. However, high growth during 
2005-08 was propelled mainly by domestic demand, which was possible when external financing was relatively abundant and the widening current account deficits can be financed through external savings. In other words, the analysis underlying the IMF staff's previous prediction is still relevant, but they underestimated the effects of strong domestic demand on growth in an enabling external environment.

23. The current economic crisis exposed the vulnerability of the economy to external shocks, and prompted a timely reassessment of the growth model prior to the crisis. There is increasing evidence that some of the factors contributing to its remarkable growth record are temporary, and a simple estimate based on the production function approach indicates that the potential growth rate after the crisis is likely to be substantially lower than the pre-crisis period.

24. Belarus can improve total factor productivity by engaging in structural reforms to improve resource allocation and enlarge the private sector. Experience in other counties provides strong evidence that Belarus will be able to resume and sustain high growth rate by pursuing these reforms. 


\section{References}

Hu, Z., and M. Khan, 1996, “Why Is China Growing So Fast?” IMF Working Paper, WP/96/75.

Konuki, T., 2008, "Estimating Potential Output and the Output Gap in Slovakia," IMF Working Paper, WP/08/275.

Oomes, N., and O. Dynnikova, 2006, "The Utilization-Adjusted Output Gap: Is the Russian Economy Overheating?” IMF Working Paper, WP/06/68. 